\title{
Results of a combination of bleomycin and triamcinolone acetonide in the treatment of keloids and hypertrophic scars
}

Resultados de uma combinação de bleomicina e triamcinolone acetonide no tratamento de quelóides e cicatrizes hipertróficas

\author{
Francisco Miguel Camacho-Martínez \\ Francisco Camacho Serrano ${ }^{3}$
}

\author{
Elena Rodríguez Rey² \\ Adriana Wagner ${ }^{4}$
}

\begin{abstract}
While treatment of keloids and hypertrophic scars normally shows modest results, we found that treatment with bleomycin was more promising. The present study was divided into two parts. In the first part the aim was to show the results using a combination of bleomycin and triamcinolone acetonide per $\mathrm{cm}^{2}$ (BTA). In the second part the objective was to determine the response to both drugs in large keloids that were divided into 1 $\mathrm{cm}^{2}$ squares, treating each square with the dose previously used. In the first part of the study, the clinical response of 37 keloids ranging from 0.3 to $1.8 \mathrm{~cm}^{2}$ treated with BTA were followed up over a period of 1- 2 years. $0.375 \mathrm{IU}$ bleomycin and $4 \mathrm{mg}$ triamcinolone acetonide were injected every 3 months. In the second part of the study we reviewed the clinical response in six patients with large keloids. The monthly dose administered never exceeded 3 IU of bleomycin. The first study showed 36 keloids (97.29\%) softening after the first dose. In the second study, 5 showed different responses (the response was complete in the four smaller keloids). The largest keloid needed 9 doses to achieve an improvement of $70 \%$. In conclusion, combined treatment with 0.375 IU of bleomycin and $4 \mathrm{mg}$ of triamcinolone acetonide to $1 \mathrm{~cm}^{2}$ was considered to be an acceptable procedure for the treatment of keloids. The best results were obtained in keloids over $1 \mathrm{~cm}^{2}$ or when divided into $1 \mathrm{~cm}^{2}$ square areas. Larger series need to be performed in order to confirm these results..
\end{abstract}

Keywords: Bleomycin; Keloid; Triamcinolone acetonide

Resumo Enquanto normalmente o tratamento de queloides e cicatrizes hipertróficas mostra resultados moderados, o tratamento com bleomicina revelou resultados mais promissores. Este estudo foi dividido em duas partes. Na primeira parte, o objetivo foi mostrar os resultados da utilização de uma combinação de bleomicina e acetonido de triancinolona por $\mathrm{cm}^{2}$ (BAT). Na segunda parte, o objetivo foi determinar a resposta aos dois medicamentos em queloides grandes, que foram divididos em quadrados de $1 \mathrm{~cm}^{2}$, tratando cada quadrado com a dose utilizada anteriormente. Na primeira parte do estudo, a resposta clínica de 37 queloides de 0,3 to $1,8 \mathrm{~cm}^{2}$ tratados com BAT foi monitorada por um período de 1 a 2 anos. Injeções de 0,375 UI de bleomicina e 4 mg de acetonido de triancinolona foram aplicadas a cada 3 meses. Na segunda parte do estudo, revisamos a resposta clínica em 6 pacientes com queloides grandes. A dose mensal administrada nunca excedeu 3 UI de bleomicina. O primeiro estudo mostrou que 36 queloides $(97,29 \%)$ amoleceram após a primeira dose. No segundo estudo, 5 mostraram diferentes respostas (a resposta foi completa nos quatro queloides menores). O queloide maior necessitou de 9 doses para apresentar melhora de 70\%. Concluindo, o tratamento combinado com 0,375 UI de bleomicina e $4 \mathrm{mg}$ de acetonido de triancinolona por $\mathrm{cm} 2$ foi considerado um procedimento aceitável para o tratamento de queloides. Os melhores resultados foram obtidos em queloides com mais de $1 \mathrm{~cm}^{2}$ ou divididos em áreas de $1 \mathrm{~cm}^{2}$. Estudos mais amplos deveriam ser realizados, para confirmar esses resultados.

Palavras-chave: Bleomicina; Queloide; Triancinolona acetonida

Received on 09.04.2012.

Approved by the Advisory Board and accepted for publication on 10.08.2012

* Study undertaken at the Deparment of Dermatology, Virgen Macarena University Hospital - Seville, Spain.

Financial Support: None

Conflict of Interest: None

Chief of Dermatology Department, Board Member of International League of Dermatology Societies - Head Professor of Dematology, Virgen Macarena University Hospital - Seville, Spain.

MD, Consultant Dermatologist - Department of Dermatology and Venereology Virgen Macarena University Hospital - Seville, Spain

MD, Consultant Traumatologist - General Surgical Department, Virgen Macarena University Hospital - Seville, Spain.

MD, Surgical Dermatology Fellowship - Department of Dermatology, Imbanaco Medical Center - Cali, Colombia.

(C)2013 by Anais Brasileiros de Dermatologia 


\section{INTRODUCTION}

Keloids are benign hyperproliferative growths of dermal collagen usually resulting from excessive tissue response to skin injury; they are characterized by a tendency to recur. However, spontaneous keloids can occur without previous skin trauma. Keloids invade clinically normal adjacent skin and are often painful or/and pruritic.

Although their etiology is not fully understood, it is well-known that the combination of high prolidase activity (up to four-fold compared to normal skin) and the increase of type I procollagen and type I collagen concentration in the tissue (especially the latter) are involved. ${ }^{1}$ There is hereditary or racial predisposition. The condition affects the presternal area, ear lobes, shoulders, ankles and/or face.

Keloids may cause pain, movement limitation, and other physical and psychological problems. The search for an effective treatment is therefore essential. Different options such as intralesional injections of bleomycin or corticosteroids either alone or combined with cryotherapy, compression therapy, silicone sheeting, radiation therapy, laser therapy, 5-fluorouracil, interferon, retinoids, imiquimod 5\% cream, tacrolimus, verapamil and botulin toxin have been used, most of them with the aim of achieving the best functional and cosmetic solution possible.-5

Bleomycin is a useful drug in dermatology for intralesional therapy to treat cutaneous warts, Bowen's disease, basal and squamous cell carcinomas and haemangiomas. ${ }^{6-11}$ Local side-effects include hyperpigmentation, pain, necrosis, and atrophy. ${ }^{12}$
Different reports present bleomycin as an effective treatment in keloid therapy and hypertrophic scars using different application methods such as dermojet, multiple needle punctures or syringe injection. ${ }^{2,12,13}$

However, the dose required per $\mathrm{cm}^{2}$ of surface and the possibility of avoiding side- effects with subsequent injections of triamcinolone acetonide has not been investigated to date in large series.

The objective of the first study was to find the ideal dose of bleomycin and triamcinolone acetonide for each $1 \mathrm{~cm}^{2}$ of keloid. In the second study the aim was to demonstrate the response of larger keloids divided into $1 \mathrm{~cm}^{2}$ squares in order to inject into each area the dose that had been previously demonstrated as being more effective.

\section{MATERIAL AND METHODS}

Between May 2004 and May 2006 we treated 10 white patients, 4 males and 6 females, aged $19-39$ years, with Fitzpatrick skin phototypes II, III and IV. Two patients (nos. 8 and 9) presented one keloid; the others had between 3 and 9. 38 keloids and 2 hypertrophic scars (patient no. 7) were included in our study (Table 1). Three keloids bigger than $2 \mathrm{~cm}^{2}$ (patients nos. 1, 4, and 6) were considered in the second study. In the first study 35 keloids of under $2 \mathrm{~cm}^{2}$ and two hypertrophic scars were treated.

The keloids were located on the back, shoulders, presternal and scapular regions (Figures 1 - 6). The hypertrophic scars were located in the right abdominal wall and right thigh. Keloids were second-

TABle 1: First Study Patients' characteristics

\begin{tabular}{|c|c|c|c|c|c|c|c|}
\hline Patient & Sex & Age & $\begin{array}{l}\text { Skin } \\
\text { Type }\end{array}$ & Etiology & Location & $\begin{array}{l}\text { Lesion } \\
\left(\text { size } \mathbf{c m}^{2}\right)\end{array}$ & $\begin{array}{l}\text { Previous } \\
\text { Treatment }\end{array}$ \\
\hline 1 & M & 19 & III & NODULOCYSTIC ACNE & $\begin{array}{l}\text { PRESTERNAL } \\
\text { BACK }\end{array}$ & $\begin{array}{l}6(0.5-1.5) \\
3(1-1.8)\end{array}$ & $\begin{array}{l}\text { SURGERY } \\
\text { LASER THERAPY }\end{array}$ \\
\hline 2 & $\mathrm{~F}$ & 23 & III & SURGERY & $\begin{array}{l}\text { PRESTERNAL } \\
\text { SHOULDER L }\end{array}$ & $\begin{array}{l}2(1.1 / 1.5) \\
2(1.2 / 1.5)\end{array}$ & $\begin{array}{l}\text { TRIAMCINOLONE ACETONIDE } \\
\text { SILICONE }\end{array}$ \\
\hline 3 & $\mathrm{~F}$ & 27 & II & SPONTANEOUS & $\begin{array}{l}\text { PRESTERNAL } \\
\text { SCAPULAR R/L }\end{array}$ & $\begin{array}{l}1(1.8) \\
2(1.0 / 1.5)\end{array}$ & NO \\
\hline 4 & M & 39 & III & NODULOCYSTIC ACNE & PRESTERNAL & $2(1.0 / 1.3)$ & TRIAMCINOLONE ACETONIDE \\
\hline 5 & M & 19 & IV & NODULOCYSTIC ACNE & PRESTERNAL & $4(0.3-1.8)$ & SILICONE \\
\hline 6 & M & 27 & III & NODULOCYSTIC ACNE & PRESTERNAL & $4(1.2-1.8)$ & NO \\
\hline 7 & $\mathrm{~F}$ & 20 & II & TRAUMATIC SCAR & $\begin{array}{l}\text { CHEST } \\
\text { ABDOMINAL WALL } \\
\text { SHOULDER L } \\
\text { RIGHT THIGH }\end{array}$ & $\begin{array}{l}2(1.0 / 1.3) \\
1(1.4) \\
1(1.5) \\
1(1.4)\end{array}$ & $\begin{array}{l}\text { NO } \\
\text { (Hypertrophic scar-HS) } \\
\text { (Hypertrophic scar-HS) }\end{array}$ \\
\hline 8 & $\mathrm{~F}$ & 28 & III & SPONTANEOUS & PRESTERNAL & $1(1.2)$ & SILICONE \\
\hline 9 & $\mathrm{~F}$ & 26 & III & SURGERY & PRESTERNAL & $1(1.5)$ & TRIAMCINOLONE ACETONIDE \\
\hline 10 & $\mathrm{~F}$ & 29 & III & TRAUMATIC SCAR & $\begin{array}{l}\text { SHOULDER L } \\
\text { SCAPULAR R }\end{array}$ & $\begin{array}{l}1(1.6) \\
3(0.6-1.3)\end{array}$ & SILICONE \\
\hline
\end{tabular}

$\mathbf{L}=$ Left

R= Right 

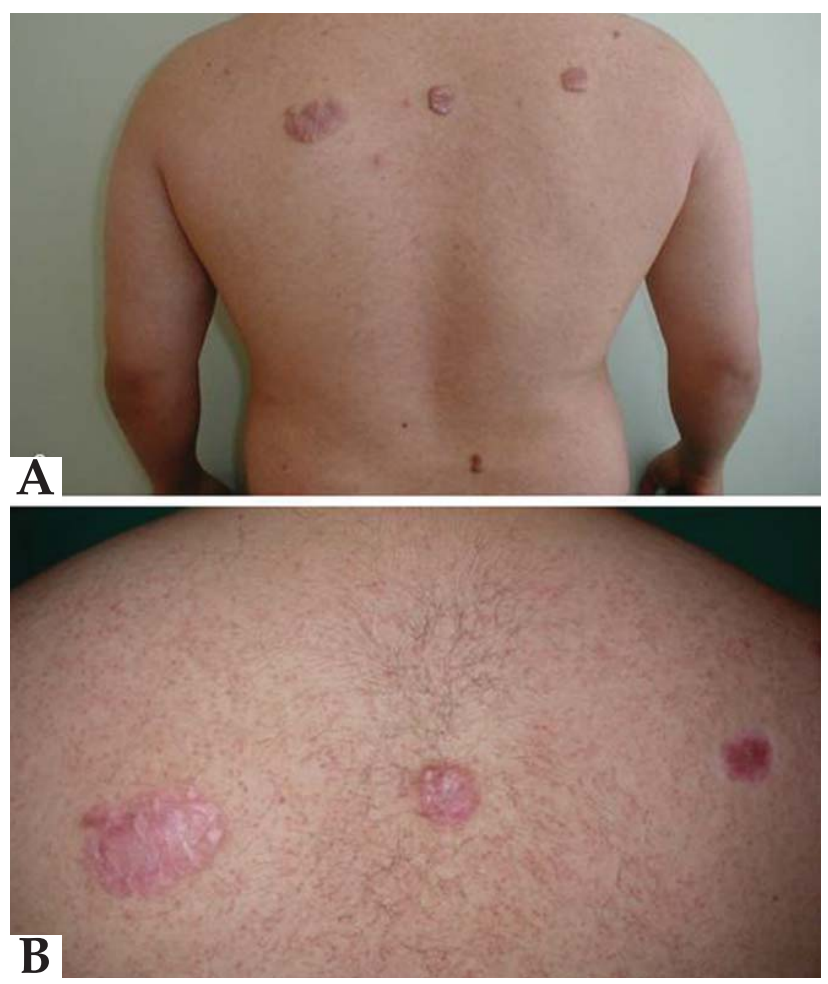

FIGURE 1: Three keloids of $1.0 \mathrm{~cm} 2,1.2 \mathrm{~cm}^{2}$ and $1.8 \mathrm{~cm}^{2}$ right-to-left on back, before (a) and after two sessions of treatment (b)
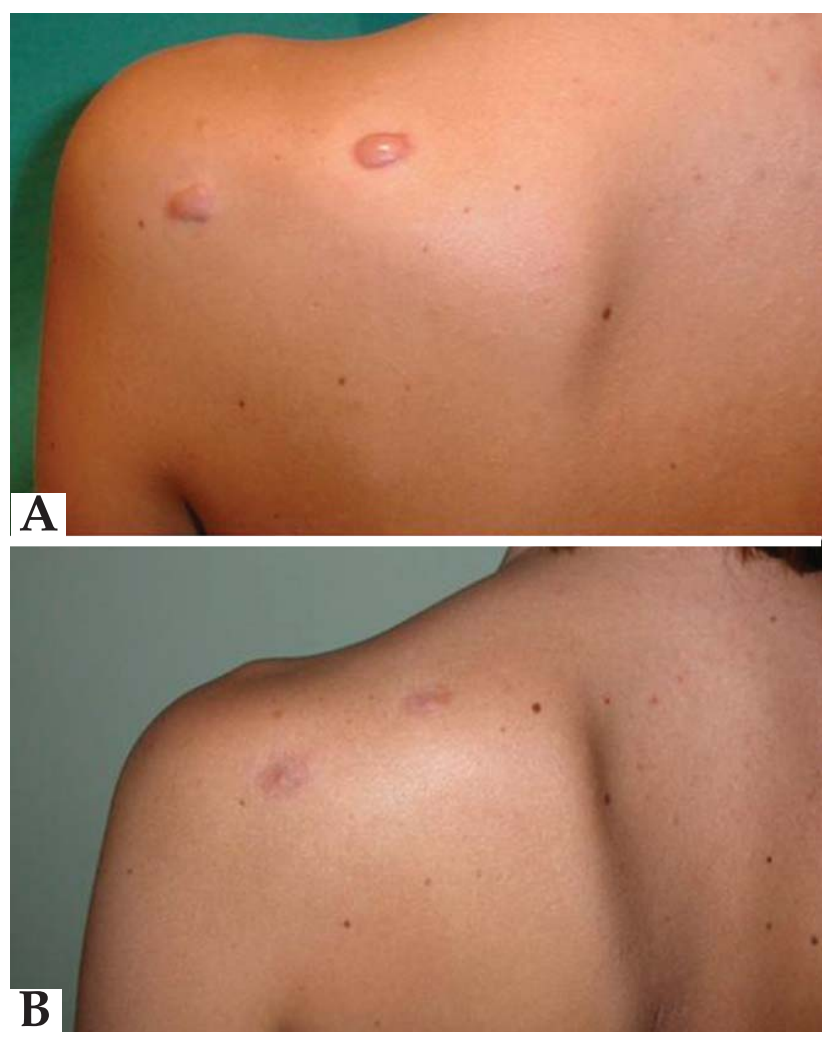

FIGURE 2: Two keloids of $1.2 \mathrm{~cm} 2$ and $1.5 \mathrm{~cm}^{2}$ on the left shoulder in a woman before (a) and after two sessions of treatment (b). Atrophy, most evident in the outer
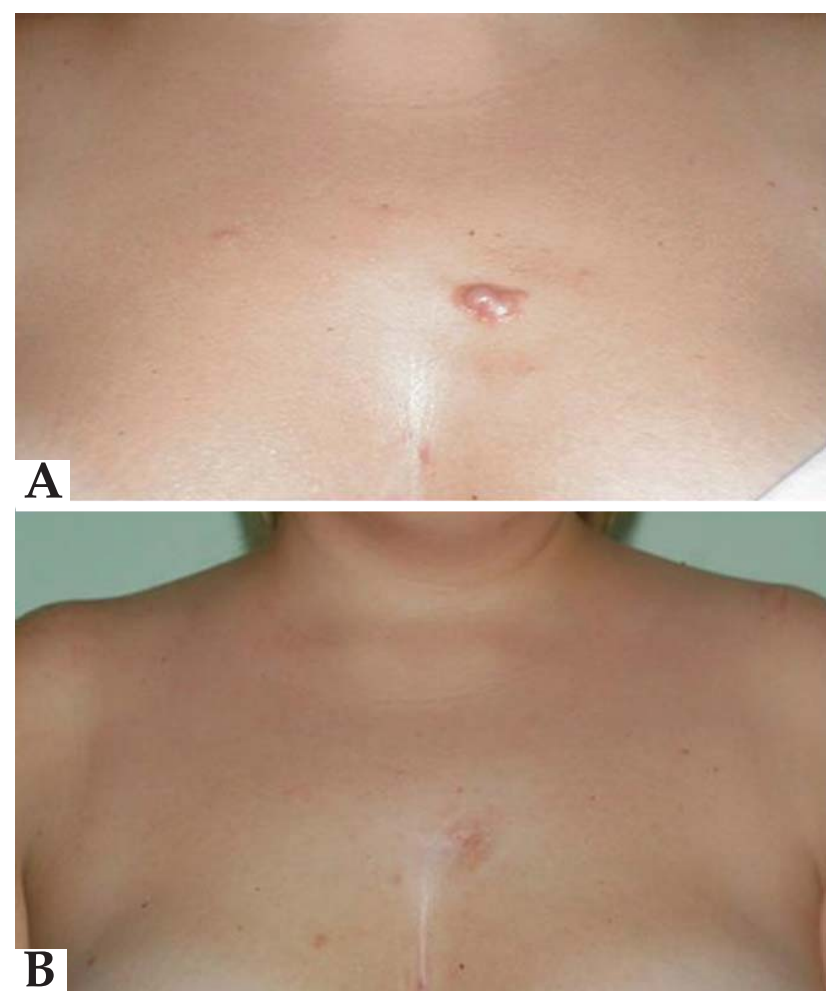

FIGURE 3: Presternal keloid of $1.8 \mathrm{~cm}^{2}$ before (a) and after two sessions of treatment $(b)$, showing complete flattening

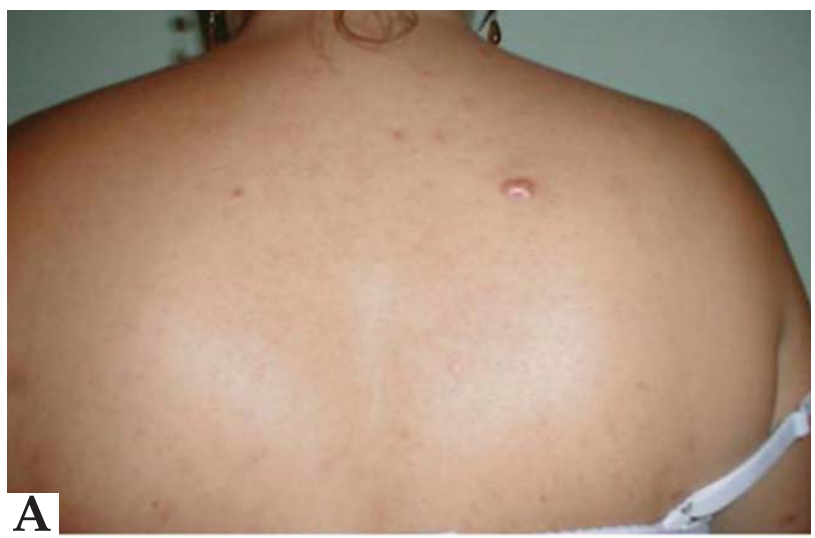

\section{B}

FIGURE 4: Keloid of $1.0 \mathrm{~cm} 2$ in right scapular region before (a) and after two sessions of treatment (b), showing significant flattening 

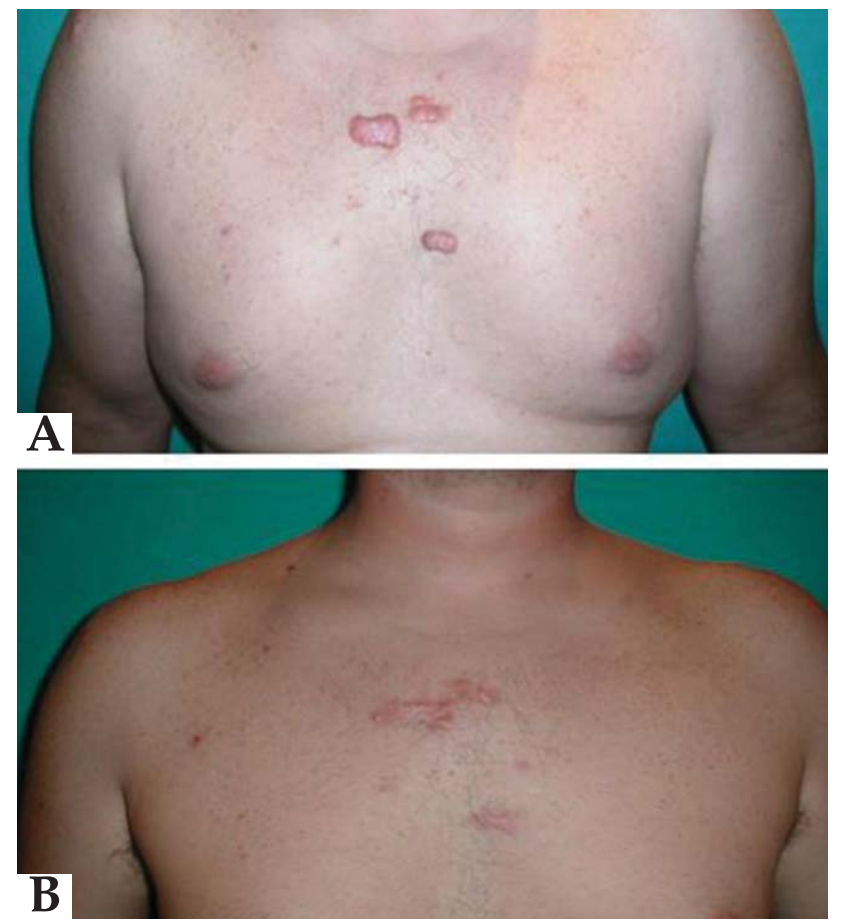

FIGURE 5: Four presternal keloids between 0.3 to $1.8 \mathrm{~cm}^{2}$ before (a) and after two sessions of treatment (b). Excellent softening but different flattening from significant to complete in relation to size

ary to acne in 4 patients (nos. 1, 4, 5 and 6); to surgery in two patients with lateral projection on the scars in relation to the stitches (nos. 2 and 9); to traumatic scars in two patients (nos. 7 and 10); and spontaneous or of unknown origin in two patients (nos. 3 and 8). Only 3 patients (nos. 3, 6 and 7) had not been referred for previous therapies (Table 1). All the patients were informed of the type of treatment and gave their written consent.

Exclusion criteria: patients under 18 years were not considered suitable for this treatment; pregnant and women likely to become pregnant women were not enrolled in the study. Regarding the keloids and hypertrophic scars, Patients being treated for keloids and hypertrophic scars during the previous six months were also excluded.

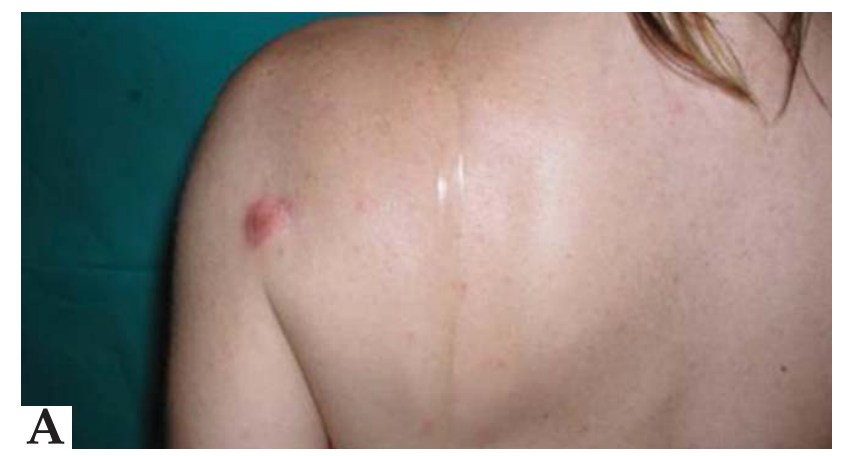

\section{B}

FiguRE 6: Large keloids of $3.96 \mathrm{~cm}^{2}$ located on left shoulder, before (a) and after three sessions of treatment (b). Complete flattening

We used the same method in all our patients. In previous studies we had injected different doses from 0.25 to $0.50 \mathrm{ml}(=0.375-0.750 \mathrm{IU})$ for keloids of $1 \mathrm{~cm}^{2}$, demonstrating that $0.25 \mathrm{ml}$ was sufficinet enough to obtain good results. In this present study we injected $0.25 \mathrm{ml}\left(=0.375 \mathrm{IU}\right.$ by $\left.\mathrm{cm}^{2}\right)$ into an area of $1 \mathrm{~cm}^{2}-11.2$ $\mathrm{cm}^{2}$ and increased the dose by $0.05 \mathrm{ml}$ for each additional $0.2 \mathrm{~cm}^{2} \cdot{ }^{14,15}$

In the second study we divided keloids into 1 $\mathrm{cm}^{2}$ squared areas (patient nos. 1, 4 and 6) and accepted three new patients with large keloids (nos. 11, 12 and 13) (Figures 7 and 8). The three latter were men aged 19-35 years, all with phototypes III, and with large keloids in the center of the chest as a result of nodulocystic acne. The size of these six keloids was $20.46 \mathrm{~cm}^{2}(6.2 \times 3.3 \mathrm{~cm})$ in patient no. $1 ; 3.96 \mathrm{~cm}^{2}(2.2 \mathrm{x}$

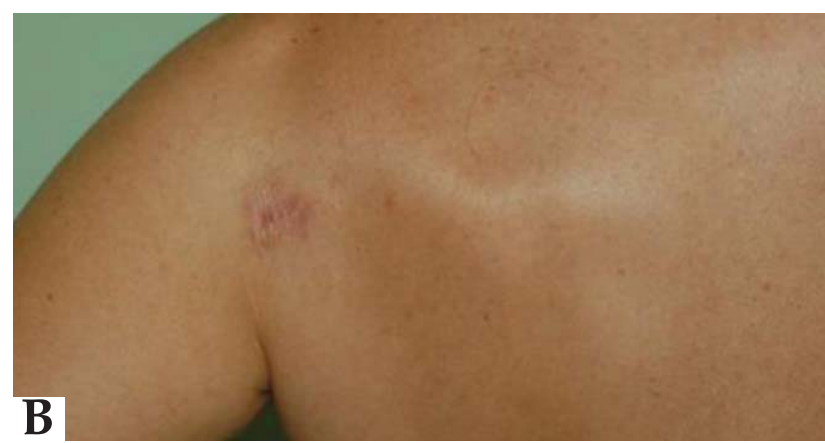

Figure 7: Keloid on left shoulder of $1.5 \mathrm{~cm}^{2}$ before (a) and after three sessions of treatment (b). Excellent softening, high significant flattening and slight atrophy 

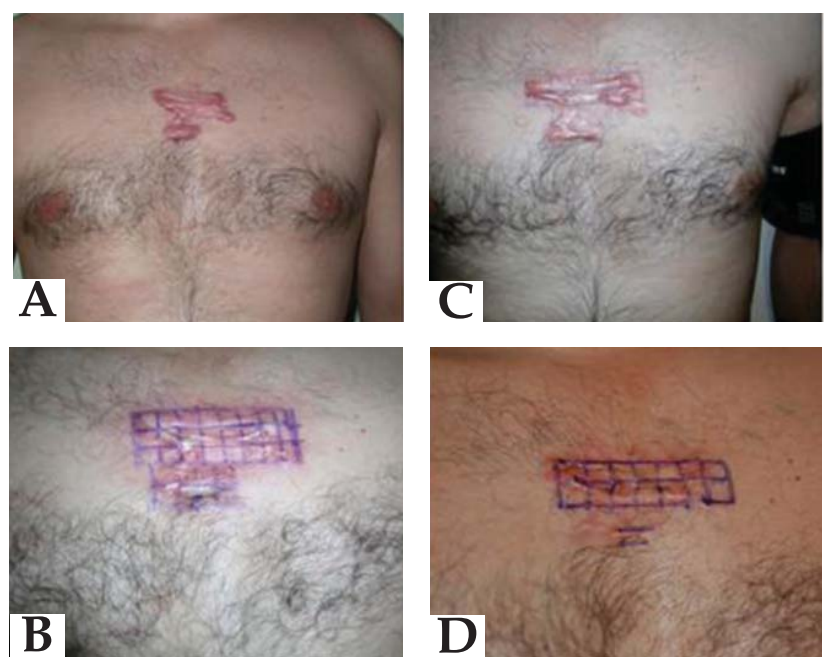

$1.8 \mathrm{~cm})$, in patient no. $4 ; 8.40 \mathrm{~cm}^{2}(4.0 \times 2.1 \mathrm{~cm})$ in patient no. $6 ; 7.04 \mathrm{~cm}^{2}(3.2 \times 2.2 \mathrm{~cm})$ in patient no. 11; $9.43 \mathrm{~cm}^{2}(4.1 \times 2.3 \mathrm{~cm})$ in patient no. 12 ; and $35.26 \mathrm{~cm}^{2}$ $(8.2 \times 3.3 \mathrm{~cm}+4.1 \times 2.0 \mathrm{~cm}$ ) in patient no. 13 (Figure 8 and Table 2).

A concentration of $1.5 \mathrm{IU} / \mathrm{ml}$ of bleomycin dilution was prepared from $15 \mathrm{IU}$ in $10 \mathrm{ml}$ of physiologic serum. The injection of bleomycin was slow - a rate of $0.05 \mathrm{ml}$ per second. We never injected more than $3 \mathrm{IU}$ of bleomycin per session. For this reason the large keloids received $3 \mathrm{IU}$ for each $8 \mathrm{~cm}^{2}$ with follow-up subsessions every 6 weeks for patient nos. 6 and 12, and monthly sessions for patients no.1 and 13 . The latter patient received his total dose in four, three and two subsessions over a total period of thirteen and a half months as the size of keloid gradually reduced. (Figure 8). In three cases only we injected $0.2 \mathrm{ml} / \mathrm{cm}^{2}$ $\left(0.3 \mathrm{IU} / \mathrm{cm}^{2}\right)$ in the first treatment, but this variant was not taken into account in the study overall. Subsequently, we infiltrated $4-5 \mathrm{mg} / \mathrm{cm}^{2}$ of a 40 $\mathrm{mg} / \mathrm{ml}$ triamcinolone acetonide solution to obtain whitening $(0.10-0.125 \mathrm{ml}$ in a syringe of $0.5 \mathrm{ml})$. We never injected more than $5 \mathrm{mg} / \mathrm{cm}^{2}$ of triamcinolone acetonide, nor a total dose of $30 \mathrm{mg}$ per keloid. The final step was to apply a silicone patch which had to
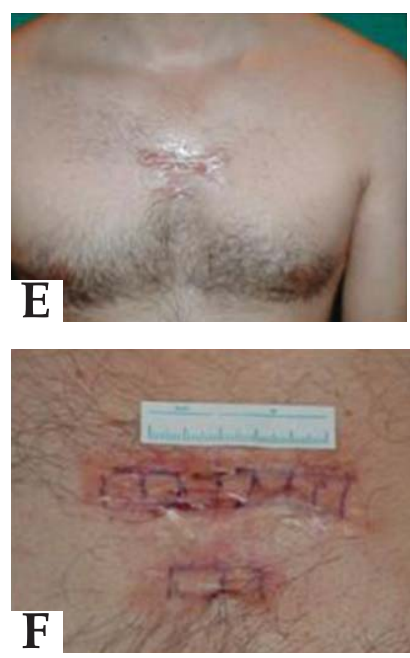

FIgURE 8: Double presternal keloid (a) divided into 24 and 8 squares up-and-down respectively (b). Reduction of numbers of 1 $\mathrm{cm}^{2}$ squared areas can be observed as result of treatment. After three sessions (nine subsessions of 4 (b), 3 (c), and 2 (d) in which maximum of 3.0 IU bleomycin was injected in each, the result showed excellent softening and highly significant flattening $(\mathrm{e}, \mathrm{f})$

be kept in place for two days. The sessions were repeated at 3 monthly intervals, with the exception of the above-mentioned larger keloids. Treatment response was evaluated in terms of flattening and softening of the lesions.

Patients were followed up every three months during 1- 2 years to observe recurrences and any side effects. The same physician assessed all the patients during their follow up (FMC), together with an external assessor.

Flattening was evaluated by comparing photos of the keloid before and after treatment and by measuring scar height (reduction percentage from baseline), classified on a 5 -point scale - " 1 " was minimal flattening (<50\%); "2" moderate flattening (50-75\%); "3' significant flattening (75-90\%); and " 4 " highly significant flattening (>90\%) and " 5 " complete flattening $(100 \%)$. Softening was evaluated according to a personal pliability scale by means of the "pinching technique": level 1 signified impossible to pinch (bad response); level 2 represented easy to pinch but with permanent erythema (partial response); and level 3 was assessed by a pinch producing an effect similar to normal skin (excellent response). We consider this personal method easier to perform than the 4-point scale commonly used in burn scars. ${ }^{16}$

TABle 2: Patients' characteristics (2nd Study)

\begin{tabular}{|c|c|c|c|c|c|c|c|}
\hline Patient & Sex & Age & Skin Type & Etiology & Location & $\begin{array}{l}\text { Lesion } \\
\left(\text { size } \mathrm{cm}^{2}\right)\end{array}$ & $\begin{array}{l}\text { Previous } \\
\text { Treatment }\end{array}$ \\
\hline 1 & M & 19 & III & Nodulocystic acne & Presternal & $1(6.2 \times 3.3)$ & Surgery \\
\hline 4 & M & 39 & III & Nodulocystic acne & Shoulder L & $1(2.2 \times 1.8)$ & Triamcinolone acetonide \\
\hline 6 & M & 27 & III & Nodulocystic acne & Presternal & $1(4.0 \times 2.1)$ & No \\
\hline 11 & M & 35 & III & Nodulocystic acne & Presternal & $1(3.2 \times 2.2)$ & Triamcinolone acetonide \\
\hline 12 & M & 28 & III & Modulocystic acne & Presternal & $1(4.1 \times 2.3)$ & No \\
\hline 13 & M & 31 & III & Nodulocystic acne & Presternal & $1(8.2 \times 3.3+4.1 \times 2.0)$ & No \\
\hline
\end{tabular}




\section{RESULTS}

The response of each keloid in both studies (1 and 2 ) is indicated in table 3 , numbered from 1 to 43 .

From an aesthetic point of view all the patients in the first study were satisfied with the final results, although in our view the results obtained in the two presternal keloids of patient No. 4 (keloid nos. 18 and 19) were not entirely satisfactory.

In 36 cases $(97.29 \%)$, partial or complete softening (level 2-3) was obtained after the first session. Complete flattening was achieved in 24 keloids $(64.86 \%)$ in the second session. Only in four keloids $(10.81 \%)$ were patients satisfied after the first session (patient no. 1 - keloids nos. 5, 6, $7\left(1-1,5 \mathrm{~cm}^{2}\right)$ and patient no. 9 - keloid no. 36 (size $1.5 \mathrm{~cm}^{2}$ ) all located in the presternal area), and two keloids (5.40\%) (no. $34,39)$ required four treatment sessions (see Figures 1 , 2, 4 and 6). Five keloids (13.51\%) (nos. 11, 12, 22, 28 and 40) achieved highly significant flattening, although no. 40 called for four sessions; and six (16.21\%) (keloid nos. 15, 18, 19, 23, 24 and 37) showed significant flattening (Figures 3, 5 and 6).

In the second study the six larger keloids, divided into $1 \mathrm{~cm}^{2}$ square areas (nos. 1, 20, 29, 41, 42 and 43 ), responded excellently after three sessions in $50 \%$ of the cases (nos. 20, 41 and 42), and partial softening after 4, 3 and 3 sessions in case nos. 1, 29 and 43 , although case 1 needed 12 subsessions, and case 43 a total of 9 subsessions, the last one completed after about 14 months of treatment (Figure 8 and Table 3). Only one case $(2.70 \%)$ achieved moderate flattening (case 1). In this keloid measuring $20.46 \mathrm{~cm}^{2}$ (patient no. 1), we performed surgery and laser therapy eight months before the intralesional infiltrations with bleomycin and triamcinolone acetonide. After twelve doses and four subsessions of $3 \mathrm{IU}$ in each $8 \mathrm{~cm}^{2}$ area, the response was 'moderate' (Table 3 ). The other large keloids (nos. 20, 29, 41, 42 and 43) were divided into 4, $9,8,10$ and 32 quadrangular areas of $1 \mathrm{~cm}^{2}$ (Figure 8.a,b). After 3 sessions on keloids 20, 29, 41 and 42 we obtained a complete flattening, but keloid no. 43 required 9 subsessions (4, 3 and 2 times each session) in order to obtain a 'highly significant' flattening, but with atrophy (Figure 8).

Three lesions (nos.11, 12 and 15) recurred within 3-12 months, and the treatment was repeated at a follow-up session three months later. After 18-24 months of follow-up, keloids of the first study and numbers 41 and 42 of the second study maintained their softening and flattening, as well as normal skin color, with the exception of no. 1 which maintained erythema and telangiectasias.

Eight keloids in the first study (nos. 13, 14, 31, $32,33,34,37,39)$ presented atrophy. This was especially evident in no. 13. All needed a twice-a-day applica-
TABLE 3: First Study Patients' characteristics

\begin{tabular}{|c|c|c|c|c|}
\hline $\begin{array}{l}\text { PATIENT No } \\
\text { KELOIDS }\end{array}$ & SESSIONS & RESULTS & SE & $\mathbf{R}$ \\
\hline 1 & & SF & U-A & \\
\hline 1 & 4 (3)[12] & 22 & - & $\Delta^{* *}$ \\
\hline 2 & 2 & 35 & & \\
\hline 3 & 2 & 35 & & \\
\hline 4 & 2 & 35 & & \\
\hline 5 & 1 & 35 & & \\
\hline 6 & 1 & 35 & & \\
\hline 7 & 1 & 35 & & \\
\hline 8 & 2 & 35 & & \\
\hline 9 & 2 & 35 & & \\
\hline \multirow{2}{*}{\multicolumn{5}{|c|}{2}} \\
\hline & & & & \\
\hline 11 & 2 & 34 & & \\
\hline 12 & 2 & 34 & & \\
\hline 13 & 2 & 35 & +++ & $\Delta$ \\
\hline 14 & 2 & 35 & ++ & $\Delta$ \\
\hline \multicolumn{5}{|l|}{3} \\
\hline 15 & 2 & 35 & & \\
\hline 16 & 2 & 33 & & \\
\hline 17 & 2 & 35 & & \\
\hline \multicolumn{5}{|l|}{4} \\
\hline 18 & 2 & 23 & & \\
\hline 19 & 4 & 23 & & \\
\hline 20 & 3 & 35 & & \\
\hline \multicolumn{5}{|l|}{5} \\
\hline 21 & 2 & 35 & & \\
\hline 22 & 2 & 34 & & \\
\hline 23 & 2 & 33 & & \\
\hline 24 & 2 & 33 & & \\
\hline \multicolumn{5}{|l|}{6} \\
\hline 25 & 2 & 35 & & \\
\hline 26 & 2 & 35 & & \\
\hline 27 & 2 & 35 & & \\
\hline 28 & 2 & 34 & & \\
\hline 29 & $3(2)[6]$ & 25 & & \\
\hline \multicolumn{5}{|c|}{ 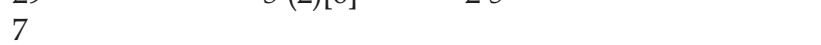 } \\
\hline 30 & 2 & 35 & & \\
\hline 31 & 2 & 35 & + & \\
\hline 32 & 2 & 35 & + & \\
\hline 33 & 2 & 35 & ++ & \\
\hline 34 & 4 & 35 & + & \\
\hline \multicolumn{5}{|l|}{8} \\
\hline 35 & 2 & 35 & & \\
\hline \multicolumn{5}{|l|}{9} \\
\hline 36 & 1 & 35 & & \\
\hline \multicolumn{5}{|l|}{10} \\
\hline 37 & 3 & 33 & + & \\
\hline 38 & 3 & 35 & & \\
\hline 39 & 4 & 35 & + & \\
\hline 40 & 4 & 34 & & \\
\hline \multicolumn{5}{|l|}{11} \\
\hline 41 & 3 & 35 & & \\
\hline \multicolumn{5}{|l|}{12} \\
\hline 42 & $3(2)[6]$ & 35 & & \\
\hline \multicolumn{5}{|l|}{13} \\
\hline 43 & $3(4-3-2)[9]+$ & 24 & - & \\
\hline
\end{tabular}

$\mathbf{S}=$ softening, $\mathbf{F}=$ flattening, $\mathbf{S E}=$ side effects, $+=$ atrophy, $\bullet=$ ulceration, $\mathbf{R}=$ recurrence $(\Delta)$, Fig= Figure, ${ }^{* *}=$ loss of follow-up.

(n): sub-session/doses each session. [n]: Total sub-sessions 
tion of minoxidil 5\% (Figure 2). Only lesion no. 13 displayed slight atrophy after 24 months of follow-up.

The large keloids of cases 1 and 43 developed necrosis of the central quadrants, followed by an ulcer and subsequenly by an atrophic scar covered with telangiectasias. As a result, case 1 was lost to followup.

Although both infiltrations are painful, none of the patients complained of pain or severe pigmentation changes in the days after the infiltration. When we compared the incidence of pain after injection of bleomycin without the subsequent injection of 4 $\mathrm{mg} / \mathrm{cm}^{2}$ triamcinolone acetonide, previously received by several patients, all the patients reported that the pain felt during several days after injection did not occur when we applied the triamcinolone immediately post-injection.

\section{COMMENTS}

Bleomycin is a cytotoxic polypeptide with antitumoral, antibacterial and antiviral properties isolated from the fungus Streptomyces verticillus. It is used as a systemic chemotherapeutical agent since its mode of action appears to inhibit DNA synthesis and DNA destruction. RNA and protein synthesis is also inhibited to a lesser extent. ${ }^{7,13}$ The active effect of bleomycin used in the treatment of keloids and hypertrophic scars may possibly be explained by the inhibition of collagen synthesis by human dermal fibroblasts or stimulated by the presence of TGF- $\beta .1$, a cytokine detected in scar tissues at high levels. ${ }^{17}$ Other action mechanisms of bleomycin on keloids might be the increase of fibroblast apoptosis or the reduction of the lysyl oxidase levels, an enzyme found in high concentrations in keloids and hypertrophic scars. ${ }^{18,19}$

Previous studies have demonstrated that intralesional injections of bleomycin in keloids and hypertrophic scars is a well-tolerated treatment, with few local and systemic side- effects, which suggests that this treatment can be used as first line therapy for keloids. ${ }^{12}$

In our experience, intralesional bleomycin is painful, especially when dermojet injected, and particularly when treating plantar warts, where the pain is extreme and unavoidable, occasionally requiring anesthetics..$^{20}$

On the other hand, the treatment of keloids with triamcinolone acetonide (TA) is a well-known, long-term standard therapy that has been employed as a single therapeutical procedure immediately after surgery, with a reduction from $50 \%$ to $91.90 \%$ of the possibility of a recurrence of keloids and of $50 \%$ to $95.24 \%$ in the case of hypertrophic scars, within 5 weeks after surgery. ${ }^{21-23}$ Unlike the anti-inflammatory effect of corticosteroids, the effect of TA is to induce a specific protein involved in the System A amino acid transport in human keloid fibroblasts that reduces the production of collagen and inhibits alpha.2macroglobulin, which in turn inhibits collagenase..$^{24,25}$ The injection must always be performed in the papillary dermis, where collagenase is produced, and not in the subcutaneous tissue, given that it may produce underlying fat atrophy. ${ }^{25}$ As for the pain caused by injecting triamcinolone acetonide, when we injected triamcinolone acetonide as the single therapeutic agent, this was certainly painful for the patient, as it was with bleomycin. For treating keloids, a number of authors have proposed injecting a dose of $10 \mathrm{mg} / \mathrm{ml}$ of TA at 3-6 ml/hour intervals, using an electric syringe and pumping 40 times, 22 times with lidocaine and 18 times without it. ${ }^{26}$ Hoigne's effect was reported after intra-keloid injection of triamcinolone acetonide and lidocaine. ${ }^{27}$ Other authors used EMLA or L-M-Y- (previously known as EMLA-Max) two hours before the procedure. ${ }^{25}$ Finally, the combined use of TA with cryotherapy seems to be better than other combinations such as 5-fluorouracil or $585 \mathrm{~nm}$ flash lamp-pumped pulsed-dye laser, or at least comparable. ${ }^{3,28,29}$ We did not employ radiation therapy as proposed by other authors. ${ }^{25,30}$ Regarding the suitable dose to be injected per $\mathrm{cm}^{2}$, we found only one report proposing 1-10 mg of TA, depending on the size of the lesion, to be applied at four-week intervals. ${ }^{31}$ Other side effects of TA frequently include hypopigmentation, which remains for between six and twelve months. ${ }^{25}$

When we injected triamcinolone acetonide immediately after bleomycin, pain was reduced in minutes or even seconds, suggesting that this combination could well beneficial, at least hypothetically.

In the course of our study the greatest difficulty was to correctly determine the exact quantity of bleomycin and triamcinolone to be injected, as well as deciding on the most suitable size of surface for such doses. Our previous experiences with triamcinolone acetonide after cryotherapy taught us which dose was best able to reduce the pain caused by inflammation after cryotherapy, although it had previously caused minimal side effects. ${ }^{3}$

With respect to the bleomycin dose, although Tanigaki and Endo applied $0.4 \mathrm{ml} / \mathrm{cm}^{2}\left(=0.60 \mathrm{IU} / \mathrm{cm}^{2}\right)$ following a local anesthetic ( $2 \%$ prilocaine hydrochloride) - probably needed because they had used the dermojet (not our current practice), we prefer to apply $0.375 \mathrm{IU}$ using insulin syringes to inject the bleomycin while slowly withdrawing the 1 -cm-long needle. ${ }^{10}$ While is no significant difference between the quantity injected by the above authors ( $0.60 \mathrm{IU})$ and our recommendation $(0.375 \mathrm{IU})$, we believe that it is simpler to inject $0.25 \mathrm{ml}$ with insulin syringes of $0.5 \mathrm{ml}$ or $1 \mathrm{ml}$. 
The maximum volume per session was $2 \mathrm{ml}$ (3 IU), sufficient to treat 8 keloids of $1 \mathrm{~cm}^{2}$ or 8 quadrants in large keloids.

In conclusion, we consider that 0.375 IU of bleomycin for each $1 \mathrm{~cm}^{2}$ is an effective and safe treatment regardless of the technique employed. When used in combination with $4 \mathrm{mg}$ triamcinolone acetonide for each $1 \mathrm{~cm}^{2}$, side effects such as necrosis and especially pain do not appear to be substantial, although this combination may increase the risk of dermal atrophy. We believe that our results were the best obtained so far, and this is the reason why we started using the technique routinely in our department for all patients presenting for treatment of keloids. However, we do believe that it is important to undertake other comparative studies in order to confirm the significance of the results we obtained.

\title{
REFERENCES
}

1. Duong HS, Zhang QZ, Le AD, Kelly AP, Kamdar R, Messadi DV. Elevated prolidase activity in keloids: correlation with type I collagen turnover. $\mathrm{Br} \mathrm{J}$ Dermatol. 2006;154:820-8.

2. Bodokh I, Brun P. Treatment of keloid with intralesional bleomycin. Ann Dermatol Venereol. 1996;123:791-4.

3. Aranzana A, Conejo-Mir JS, Camacho F. Combined treatment of cryosurgery, steroids and surgery in keloids. Giorn Ital Dermatol Chirur Oncol. 1993;2:77-79.

4. Stashower ME. Successful treatment of earlobe keloids with imiquimod after tangential shave excision. Dermatol Surg. 2006;32:380-6.

5. Berman B, Villa AM, Ramirez CC. Novel opportunities in the treatment and prevention of scarring. J Cutan Med Surg. 2004;8:S32-6.

6. Horn MS. Bleomycin treatment of warts. Cutis. 2005;76:25

7. Lewis TG, Nydorf ED. Intralesional bleomycin for warts: a review. J Drugs Dermatol. 2006;5:499-504.

8. Ota M, Kawashima M, Mitsuishi T. Multiple Bowen's disease of the fingers. Eur J Dermatol. 2002;12:275-7.

9. Glass LF, Jaroszeski M, Gilbert R, Reintgen DS, Heller R. Intralesional bleomycinmediated electrochemotherapy in 20 patients with basal cell carcinoma. J Am Acad Dermatol. 1997;37:596-9

10. Tanigaki T, Endo H. A case of squamous cell carcinoma treated by intralesional injection of oil bleomycin. Dermatologica. 1985;170:302-5.

11. Muir T, Kirsten M, Fourie P, Dippenaar N, Lonescu GO. Intralesional bleomycin injection $(\mathrm{IBI})$ treatment for haemangiomas and congenital vascular malformations. Pediatr Surg In. 2004;19:766-73.

12. Saray Y, Gulec AT. Treatment of keloids and hypertrophic scars with dermoje injections of bleomycin: a preliminary study. Int J Dermatol. 2005;44:777-84.

13. España A, Solano T, Quintanilla E. Bleomycin in the treatment of keloids and hypertrophic scars by multiple needle punctures. Dermatol Surg. 2001;27:23-7.

14. Camacho FM, García-Hernández MJ. Modelado cutáneo (Resurfacing). Concepto y fundamentos. In: Cisneros JL, Camacho FM, Trelles MA, editores. Láser en Dermatología y Dermocosmética. Madrid: Aula Médica Ed; 2008. p. 353-65

15. Camacho FM. Tumores benignos de la piel. In: Vilata Corell JJ, editor. Manual de Dermatología y Venereología. Madrid: Panamericana Ed; 2008. p. 367-403.

16. Sullivan T, Smith J, Kermode J, Mclver E, Courtemanche DJ. Rating the burn scar J Burn Care Rehabil. 1990;11:256-60.

17. Hendricks T, Martens MF, Huyben CM, Wobbes T. Inhibition of basal and TGF betainduced fibroblast collagen synthesis by antineoplastic agents. Implications for wound healing. Br J Cancer. 1993;67:545-50.

18. Appleton I, Brown NJ, Willoughby DA. Apoptosis, necrosis, and proliferation: possible implications in the etiology of keloids. Am J Pathol. 1996;149:1441-7.

19. Yeowell HN, Marshall MK, Walker LC, Ha V, Pinnell SR. Regulation of lysyl oxidase mRNA in dermal fibroblasts from normal donors and patients with inherited connective tissue disorders. Arch Biochem Biophys. 1994; 308:299-305.

20. Agius E, Mooney JM, Bezzina AC, Yu RC. Dermojet delivery of bleomycin for the treatment of recalcitrant plantar warts. J Dermatol Treat. 2006;17:112-6.

21. Kiil J. Keloids treated with topical injections of triamcinolone acetonide (kenalog). Immediate and long-term results. Scand J Plast Reconstr Surg. 1977;11:169-72.

22. Berman B, Flores F. The treatment of hypertrophic scars and keloids. Eur J Dermatol. 1998;8:591-5.

23. Chowdri NA, Masarat M, Mattoo A, Darzi MA. Keloids and hypertrophic scars: results with intraoperative and serial postoperative corticosteroid injection therapy. Aust N Z J Surg. 1999;69:655-9.

24. Russell SB, Russell JD, Trupin JS. Hydrocortisone induction of system A amino acid transport in human fibroblasts from normal dermis and keloid. J Biol Chem. 1984; 259:11464-9.

25. Kelly AP. Medical and surgical therapies for keloids. Dermatol Ther. 2004;17:2128.

26. Ono N. Pain-free intralesional injection of triamcinolone for the treatment of keloid Scand J Plast Reconstr Surg Hand Surg. 1999; 33:89-91.

27. Humbert P, Girardin P, Aubin F. Fear of dying after intra-keloid injection of triamcinolone acetonide and lidocaine: Hoigne's syndrome. Ann Dermatol Venereol. 2001;128:762.

28. Yosipovitch G, Widijanti Sugeng M, Goon A, Chan YH, Goh CL. A comparison of the combined effect of cryotherapy and corticosteroid injections versus corticosteroids and cryotherapy alone on keloids: a controlled study. J Dermatolog Treat. 2001;12:87-90.

29. Manuskiatti W, Fitzpatrick RE. Treatment response of keloidal and hypertrophic sternotomy scars: comparison among intralesional corticosteroid, 5-fluorouracil, and 585-nm flashlamp-pumped pulsed-dye laser treatments. Arch Dermatol. 2002; 138:1149-55.

30. Mutalink S. Treatment of keloids and hypertrophic scars. Indian J Dermatol Venereol. 2005;71:3-8.

31. Muneuchi G, Suzuki S, Onodera M, Ito O, Hata Y, Igawa HH. Long-term outcome of intralesional injection of triamcinolone acetonide for the treatment of keloid scars in Asian patients. Scand J Plast Reconstr Surg Hand Surg. 2006;40:111-6.

\author{
MAILING ADDRESS: \\ Francisco Miguel Camacho-Martínez \\ Avenida Doctor Fedriani, 9 \\ 41009 - Seville \\ Spain \\ E-mail: camachodp@medynet.com
}

How to cite this article: Camacho-Martínez FM, Rodriguez-Rey E, Camacho-Serrano F, Wagner A. Results of a combination of bleomycin and triamcinolone acetonide in the treatment of keloids and hypertrophic scars. An Bras Dermatol. 2013;88(3):387-94. 